\title{
Investigation of mechanical properties and crack resistance parameters of steel reinforcements of reinforced concrete structures of long-term special term
}

\author{
Petro Kulikov ${ }^{1}$, Yulia Makarenko ${ }^{2}$, Victor Khoruzhiy ${ }^{1,3}$, Valeriy Makarenko ${ }^{1,4}$ \\ ${ }^{1}$ Kyiv National University of Construction and Architecture \\ Povitroflotskiy avenue 31, Kyiv, Ukraine, 03037 \\ gti05@ukr.net \\ 2 University of Manitoba, 750 Bannatyne Avenue, Winnipeg, Canada \\ green555tree@gmail.com, orcid.org/0000-0003-1252-4231 \\ 1,3 xoruji@ukr.net, orcid.org/0000-0002-5314-0483 \\ 1,4 orcid.org/0000-0001-6668-3957
}

Received 11.09.2021, accepted after revision 25.09.2021

https://doi.org/10.32347/uwt2021.11.1801

\begin{abstract}
It is known that the fatigue process begins with the plastic deformation of the surface layers of the metal fittings. Moreover, the displacement of dislocations under conditions of realternating loads is observed at loads below the elastic limit of the metal. The rate of local plastic deformation during cyclic deformation is several orders of magnitude higher than the rate of deformation under static loading. Dislocation slip begins in grains with a favorable orientation near stress concentrators. As the number of cycles in the surface layers increases, the density of dislocations and the number of vacancies increases. When the base number of $\mathrm{N}_{R}$ cycles is reached, a surface reinforced layer of metal with a large number of germinal cracks is formed, the size of which does not reach a critical value. Increasing the number of cycles cannot cause further development of fracture in such a layer. Only when the stresses exceed the endurance limit of the crack reach a critical length, after which the process of their discharge into the main crack begins with the spread of the latter. The results of experimental studies indicate a strong effect of diffusion hydrogen on static and cyclic parameters of crack resistance. It was found that with increasing flooding, especially when the hydrogen content exceeds $5 \mathrm{~cm}^{3} / 100 \mathrm{~g}$, both static strength and long-term strength (fatigue) decrease sharply. Moreover, for these areas of hydrogen solution in reinforcing steel is characterized by a viscous nature of fracture, while for heavily flooded reinforcement (from 5 to $12 \mathrm{~cm}^{3} / 100 \mathrm{~g}$ is charac-
\end{abstract}

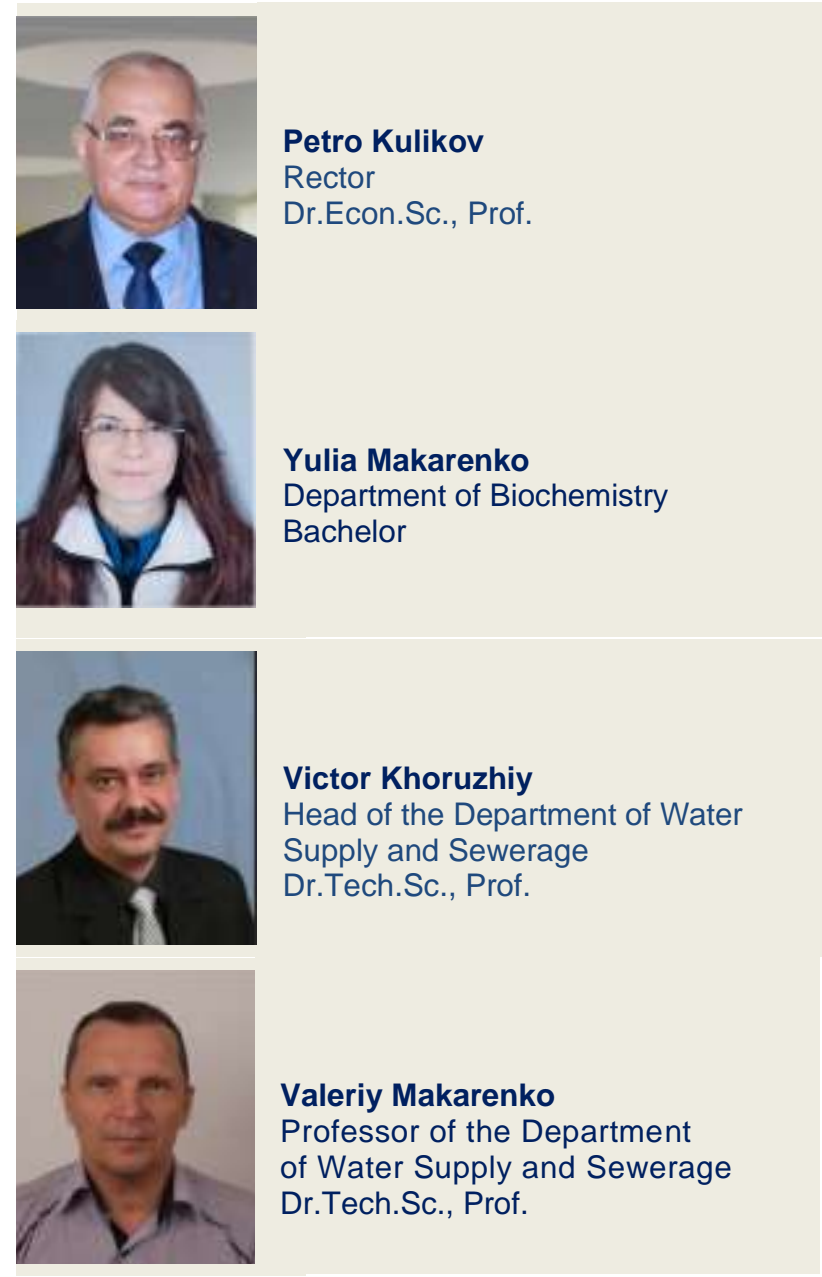

terized by brittle fracture by the mechanism of microfission in the hardened (martensite or troost- 
ite structure). allowed to determine the optimal hydrogen content in reinforcing steel $\left(3 \ldots .5 \mathrm{~cm}^{3}\right.$ $/ 100 \mathrm{~g}$ ), the excess of which will reduce the crack resistance of reinforcement during long-term operation, especially in corrosive environments. The results of the research confirm the above data. bainite structure y sharply reduces the crack resistance of reinforcing steel, which makes it impossible to use in the manufacture of reinforcement involved in reinforced concrete structures designed for long-term operation (more than $50 \ldots 60$ years). Thus, the obtained diagram can be recommended to designers of reinforced concrete structures for hydraulic purposes, as it greatly facilitates the reasonable choice of reinforcement in the development of reinforced concrete structures for responsible and long-term use.

Keywords: crack resistance, flooding, fatigue, cyclicity, fittings.

\section{INTRODUCTION}

It is known [1 - 5] that the resistance of the metal to fatigue failure is characterized by the limit of endurance (fatigue), ie it is the highest stress that can withstand the metal without failure at any number of cycles. The endurance limit is most often determined in tests with alternating symmetric cycle $(\mathrm{R}=-1)$, and therefore the endurance limit is denoted by $\sigma_{-1}$.

As a rule, the endurance limit is limited to $10^{7}$ cycles (this number of cycles is called the test base). Thus, it can be noted that the endurance limit is the maximum cycle stress that can withstand the material without destruction at the base number of cycles (for ferrous metals, this base is $10^{7}$ cycles). Then on fatigue curves it is possible to find such important indicator, as durability at fatigue under which accept number of cycles of loading which maintains steel at destruction at a certain pressure.

It is known from the literature [1] that the endurance limit in metal correlates well with the mechanical properties of metals. Thus, the value of $\sigma_{-1}$ is on average $(0.4 \ldots 0.6) \sigma_{\mathrm{B}}$ - for carbon and alloy steels; $(0.3 \ldots .5) \sigma_{\mathrm{B}}-$ for bronze and brass. This characteristic can be similarly compared with Brinell hardness:

$$
\begin{aligned}
& -\sigma_{-1}=(0.128 \ldots 0.156) \mathrm{HB}-\text { for carbon } \\
& \text { steels; } \\
& -\sigma_{-1}=(0.168 \ldots 0.222) \mathrm{HB}-\text { for alloy steels; } \\
& -\sigma_{-1}=0.19 \mathrm{HB}-\text { for aluminum alloys. }
\end{aligned}
$$

It is known from modern fracture mechanics $[2 \ldots 4]$ that with increasing number of cycles at any stresses above the endurance limit in metal, the following processes occur sequentially:

1) plastic deformation;

2) the formation of cracks, the cells of which are non-metallic inclusions (HB);

3) gradual development of some of them with the predominant spread of the main crack;

4) rapid final destruction.

The process of fatigue begins with the plastic deformation of the surface layers of the metal fittings. Moreover, the displacement of dislocations under conditions of re-alternating loads is observed at loads below the elastic limit of the metal. The rate of local plastic deformation during cyclic deformation is several orders of magnitude higher than the rate of deformation under static loading. Dislocation slip begins in grains with a favorable orientation near stress concentrators. As the number of cycles in the surface layers increases, the density of dislocations and the number of vacancies increases. When the basic number of $\mathrm{N}_{\mathrm{R}}$ cycles is reached, a surface reinforced layer of metal with a large number of germinal cracks is formed, the size of which does not reach a critical value (Fig. 1). Increasing the number of cycles cannot cause further development of fracture in such a layer. Only when the stresses exceed the endurance limit of the crack reach a critical length (Fig. 2), after which the process of their discharge into the main crack begins with the spread of the latter.

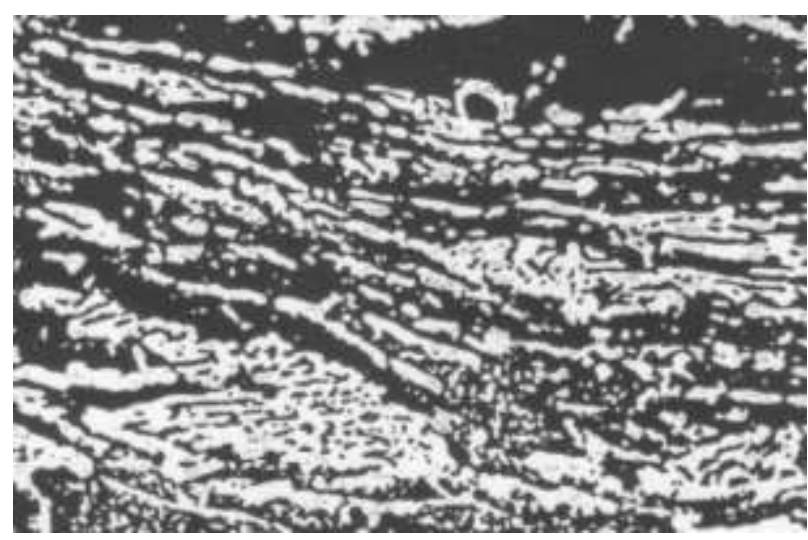

Fig. 1. Embryonic microcracks in the surface layers of reinforcing rods $(\times 4800)$ 


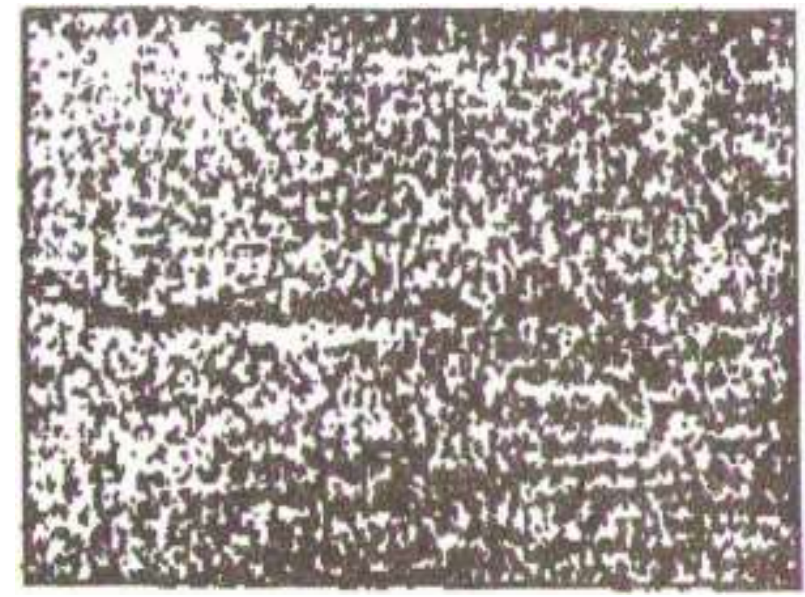

Fig. 2. The main crack in the surface layers of steel reinforcement of reinforced concrete structures of long operation in an aggressive environment $(\times 200)$

\section{FORMULATION OF PROBLEMS AND RELEVANCE OF THE TOPIC}

The ultimate stresses at which the process begins, for example, hydrogen sulfide fracture (HSF), are recommended as criteria for comparing the stability of different reinforcing steels $[5,6]$. One of the important factors influencing the resistance to HSF is the composition and structure of steel. Yes, carbon has a significant effect on HSF. It is known $[6,7]$ that with increasing amount of carbon the tendency of hardened steels to HSF increases due to increasing internal stresses. Hydrogen diffusing into the metal, even in small quantities $\left(2 \ldots 3 \mathrm{~cm}^{3} / 100 \mathrm{~g}\right)$ does not cause sufficient for the development of cracks of local plastic deformations in strong metal. It is believed that steel loses its viscoelastic characteristics at a hydrogen content in the range of $7 \ldots 12 \mathrm{~cm}^{3} / 100 \mathrm{~g}$ [8]. However, as established in [9], hydrogen fragility can occur with a small amount of absorption (absorbed) hydrogen. Thus, in steel with a tensile strength of $1600 \mathrm{MPa}$, doped with $0.7 \% \mathrm{Cu}, 0.25 \% \mathrm{Mo}$, $0.8 \% \mathrm{Nb}$ and $0.025 \% \mathrm{Al}$, a decrease in plastic properties $(\delta)$ was observed from 45 to $3 \%$ at the level of flooding $0.03 \mathrm{~cm}^{3} / 100 \mathrm{~g}$.

It should be noted that the analysis of literature sources of domestic and foreign research- ers does not provide an unambiguous answer to the question of the influence of hydrogen and alternating stresses on the embrittlement of reinforcing steel of different brands, and the results of experimental studies are usually obtained in different conditions different external factors, and therefore characterized by contradictions, making them difficult to compare and draw final conclusions, although the problem of degradation of reinforced concrete structures is relevant and, moreover, is important for the construction industry of Ukraine, resulting in additional experimental and theoretical studies.

The purpose of the work - research of mechanical properties and parameters of crack resistance of steel samples of various brands intended for production of armature of reinforced concrete designs of long service life in aggressive environments.

\section{METHODS OF EXPERIMENTAL RESEARCH, MATERIALS, CRITERIA AND EQUIPMENT}

The object of research was reinforcing steel of the following grades: $16 \Gamma 2 \mathrm{~A} \Phi ; 20 \Phi$; 09Г2ФБ; 15ХСНДА; 10ХСНДА and 06Г2Б, that is steel carbon, low-alloy, which had a structure of ferritic-perlite, sorbitol and troostite and martensitic with a coefficient of endurance $\mathrm{K}_{\mathrm{V}}=0.40 \ldots 0.50$.

After fabrication, the reinforcement samples were subjected to different heat treatment modes depending on the steel grade and obtaining the desired type of structure. The samples were polished with a grinding skin with a grain size of $3 / 0$, and then subjected to tempering in a vacuum chamber at $620^{\circ} \mathrm{C}$ for $30 \mathrm{~min}$ to remove residual stresses. The samples were tested on the setpoint of the model "Instron" (UK). The tests were performed in air. The impact of the aggressive environment was absent. We add that the tests were performed according to the requirements of the Specification of the International Association of Corrosives (Specification Tenquiz Oil and Gas Plant //Prozess Plant. Lurgi code: 65102-00-MALTENGUIZ II. Specification SP.SPC-62900XP-007). Fractographic and metallographic 
studies were performed using an electron scanning microscope model "YSM-35CF" (firm "Jeol", Japan). Mechanical tests and the type of samples of cut rebar rods met the requirements set out in the literature $[1,5]$.

\section{RESEARCH RESULTS AND THEIR DISCUSSION}

In experimental studies, the following steels were used as an object 15ХСНДА, 10 ХСНДА, 16Г2АФ, 06Г2Б, 08ХМЧА, 16Г2АФ, 17Г2СФ, 09Г2ФБ, 09Г2С, 20A.

It is established that steel has the following chemical composition and mechanical characteristics:

- steel 20A: $\mathrm{S}_{\max }=0.012 \% ; \mathrm{P}_{\max }=0.015 \%$; $\sigma_{\mathrm{v}}=502 \ldots 527 \mathrm{~N} / \mathrm{mm}^{2} ; \quad \sigma_{\mathrm{T}}=372 \ldots .509 \mathrm{~N} / \mathrm{mm}^{2}$; $\sigma_{\mathrm{T}} / \sigma_{\mathrm{v}} \leq 0.8 ; \quad \delta \geq 25 \% ; \quad \mathrm{HRB}<92 ; \quad \mathrm{KCV}, \quad \mathrm{Jcm}^{2}=$
$79.4 \ldots 166.5 \quad\left(+20^{\circ} \mathrm{C}\right) ; \quad=39.2 \ldots 88.2 \quad\left(-40^{\circ} \mathrm{C}\right)$; score of grain according to GOST 5639-82: $\geq 8$; score according to HB (GOST 1778-80): $\leq 2.5$; stripe PF according to GOST 5640-88: $\leq 2$;

- steel 08XMЧA: $\mathrm{S}_{\max }=0.015 \%$; $\mathrm{P}_{\max }=0.015 \% ; \quad \sigma_{\mathrm{v}}=502 \ldots 509 \mathrm{~N} / \mathrm{mm}^{2} \quad \sigma_{\mathrm{T}}=$ $378 \ldots 470 \mathrm{~N} / \mathrm{mm}^{2} ; \quad \sigma_{\mathrm{T}} / \sigma_{\mathrm{v}} \leq 0.8 ; \quad \delta \geq 25 \%$; $\mathrm{HRB}<95$; $\quad \mathrm{KCV}$, $\mathrm{Jcm}^{2}=107.8 \ldots 177.5\left(+20^{\circ} \mathrm{C}\right) ;=49.3 \ldots 79.2$ $40^{\circ} \mathrm{C}$ ); score of grain according to 5639-82: $\geq 9$; score according to HB (GOST 1778-80): $\leq 2.5$; stripe PF according to GOST 5640-88: $\leq 2$;

- steel 20Ф: $\mathrm{S}_{\max }=0.008 \% ; \mathrm{P}_{\max }=0.012 \%$; $\sigma_{\mathrm{v}}=470 \mathrm{~N} / \mathrm{mm}^{2} \quad \sigma_{\mathrm{T}}=338 \ldots 402 \mathrm{~N} / \mathrm{mm}^{2}$; $\sigma_{\mathrm{T}} / \sigma_{\mathrm{v}} \leq 0.8 ; \quad \delta \geq 25 \% ; \quad \mathrm{KCV}, \mathrm{Jcm}^{2}=90 \ldots 98.2(-$ $40^{\circ} \mathrm{C}$ ); score of grain according to GOST 563982 : $\geq 9$; score according to HB (GOST 1778-80): $\leq 2.5$; stripe PF according to GOST 5640-88: $\leq 2$;

Table 1. Chemical composition of steels 10ХСНДА and 15ХСНДА

\begin{tabular}{|c|c|c|c|c|c|c|c|}
\hline \multirow{2}{*}{ Steel brand } & \multicolumn{7}{|c|}{ Mass fraction of elements\% } \\
\cline { 2 - 8 } & $\mathrm{C}$ & $\mathrm{Si}$ & $\mathrm{Mn}$ & $\mathrm{Cr}$ & $\mathrm{Ni}$ & $\mathrm{Cu}$ & $\mathrm{Nb}$ \\
\hline 10ХСНДА & $\leq 0.12$ & $0.8 \ldots 1.2$ & $0.08 \ldots 0.98$ & $0.32 \ldots 0.62$ & $0.22 \ldots 0.63$ & $0.38 \ldots 0.58$ & $0.28 \ldots 0.58$ \\
\hline 15 ХСНДА & $0.1 \ldots 0.15$ & $0.4 \ldots 0.75$ & $0.62 \ldots 0.89$ & $0.32 \ldots 0.58$ & $0.22 \ldots 0.51$ & $0.21 \ldots 0.39$ & $0.03 \ldots 0.58$ \\
\hline
\end{tabular}

Note the mass fraction of $S$ and $P<0.010-0.015 \%$; nitrogen to $0.012 \%$. An admixture of niobium and vanadium in the amount of 0.08-0.12\% is allowed.

Table 2. Mechanical properties of rolled steel 10 ХСНДА and 15 ХСНДА

\begin{tabular}{|c|c|c|c|c|c|}
\hline \multirow{2}{*}{$\begin{array}{l}\text { Steel } \\
\text { Brand }\end{array}$} & $\sigma_{\mathrm{T}}$ & $\sigma \mathrm{V}$ & \multirow{2}{*}{$\begin{array}{c}\text { Relative } \\
\text { lengthening, \% }\end{array}$} & \multicolumn{2}{|c|}{$\begin{array}{c}\text { Impact strength, } \\
\text { RCU, } J / \mathrm{cm}^{2}\end{array}$} \\
\hline & \multicolumn{2}{|c|}{$\mathrm{N} / \mathrm{mm} 2$} & & $+20^{\circ} \mathrm{C}$ & $-40^{\circ} \mathrm{C}$ \\
\hline 10ХСНДА & $422 \ldots 500$ & $560 \ldots 650$ & $\geq 21 \ldots 24$ & 70 & 54 \\
\hline 15ХСНДА & $390 \ldots 495$ & $520 \ldots 630$ & $\geq 22 \ldots .25$ & 68 & 56 \\
\hline
\end{tabular}

Table 3. Physical characteristics of the $\alpha$-phase

\begin{tabular}{|c|c|c|c|}
\hline \multirow{2}{*}{ Designation } & \multicolumn{3}{|c|}{ Physical characteristics of the $\alpha$-Fe phase } \\
\cline { 2 - 4 } & $\begin{array}{c}\text { Crystal lattice } \\
\text { period, } \mathrm{nm}\end{array}$ & $\begin{array}{c}\text { Density of dislocations, } \\
\rho \cdot 10^{9}, \mathrm{~cm}^{-2}\end{array}$ & Lattice curvature, $\mathrm{cm}^{-1}$ \\
\hline 10ХСНДА & 0.28683 & $1.57 \ldots 2.17$ & $440 \ldots 535$ \\
\hline 15ХСНДА & 0.28723 & $1.7 \ldots 2.23$ & $557 \ldots 638$ \\
\hline Tabular value of $\alpha-\mathrm{Fe}$ & 0.28664 & - & - \\
\hline
\end{tabular}


- steel 06X1: $\mathrm{S}_{\max }=0.005 \% ; \mathrm{P}_{\max }=0.010 \%$; $\sigma_{\mathrm{v}}=512 \mathrm{~N} / \mathrm{mm}^{2} ; \quad \sigma_{\mathrm{T}}=386 \ldots 512 \mathrm{~N} / \mathrm{mm}^{2} ; \sigma_{\mathrm{T}} / \sigma_{\mathrm{v}} \leq$ $0.8 ; \delta \geq 25 \% ; \mathrm{HRB} \leq 92 ; \mathrm{KCV}, \mathrm{Jcm}^{2}=147\left(-40^{\circ} \mathrm{C}\right)$; score of grain according to GOST 5639-82: $\geq 9$; score according to HB (GOST 1778-80): $\leq 2.5$; stripe PF according to GOST 5640-88: $\leq 2$.

Tensile tests (GOST 1497-88) of samples of the type "gagariki" were performed on the installation of the model "Instron" (UK).

Impact strength was determined according to GOST 9454-88. Under the impact toughness should take the impact work related to the initial cross-sectional area of the sample at the hub $\mathrm{KS}=\mathrm{A} / \mathrm{F}$, where $\mathrm{A}-$ the work spent on breaking the sample (fixed on the scale of the pendulum copra) (GOST 10707-82). The size of the impact samples was $10 \times 10 \times 56 \mathrm{~mm}$. The radius of the bottom of the incision $\mathrm{r}=1 \pm 0.07 \mathrm{~mm} \quad$ (incision Menage); $\mathrm{r}=1 \pm 0.025 \mathrm{~mm}$ (Charpy incision). The specimens were tested for a three-point bending on a pendulum swing with an impact energy of up to $300 \mathrm{~J}$. The distance between the supports for mounting the specimens was $40 \pm 0.5 \mathrm{~mm}$.

Hardness (GOST 9012-59) was determined on a hardness tester model TШ-2.

Table 4. Mechanical characteristics of steels

\begin{tabular}{|c|c|c|c|c|}
\hline \multirow{2}{*}{ Steel brand } & $\sigma_{\mathrm{T}}$ & $\sigma_{\mathrm{v}}$ & \multirow{2}{*}{$\delta, \%$} & $\begin{array}{c}\mathrm{KCV}, \mathrm{J} / \mathrm{cm} 2 \\
\text { at temperatures } \\
\mathrm{t}=-40^{\circ} \mathrm{C}\end{array}$ \\
\cline { 2 - 3 } & \multicolumn{2}{|c|}{$\mathrm{MPa}$} & 32 & 33 \\
\hline 15ХСНДА & 420 & 556 & 29 & 39 \\
\hline 10ХСНДА & 395 & 515 & 28 & 44 \\
\hline 16Г2АФ & 446 & 595 & 24 & 38 \\
\hline 06Г2Б & 450 & 605 & & 24 \\
\hline
\end{tabular}

Table 5. Sulfur content in steels

\begin{tabular}{|c|c|}
\hline Steel brand & Sulfur content, $\%$ \\
\hline 15ХСНДА & 0.03 \\
\hline 10ХСНДА & 0.032 \\
\hline 16Г2АФ & 0.021 \\
\hline 06Г2Б & 0.012 \\
\hline 08ХМЧА & $0.005 \ldots 0.01$ \\
\hline
\end{tabular}

The experimental steel of the conventional grade 08XMЧA was used in the research, which was created on the basis of the improvement of steel $06 \mathrm{X} 1$ due to the economical modification of this steel by an alloying element from among rare earth metals - cerium in the amount of $0.02 \ldots 0.03 \%$. This steel is characterized by a very low content of sulfur and phosphorus, in particular, their content is limited to $0.05 \ldots 0.10 \%$. The content of other steel ingredients was as follows: Mn 0.57; Cr 0.9; Ni 0.12; Mo 0.25; Si 0.08...0.1\%.

In addition, in some experimental tests used steel grade $20 \Phi$, i.e. vanadium steel with a vanadium content of $1.2 \ldots 1.55$. This provided a low sulfur content - no more than $0.95 \ldots 0.18 \%$. And carbon was about $0.2 \ldots 0.23 \%$.

The results of the research presented in Fig. 2 confirm the data of Fig. 1. Thus, it can be seen from Fig. 2 that carbon and low-alloy sieves, which are characterized by ferriticpearlite and sorbitol structure provides high resistance primarily to prolonged fatigue, and the transition to steels with martensite structure or tempered (bainite transition jet) structure of bainite sharply reduces the crack resistance of reinforcing steel, which makes it impossible to use in the manufacture of reinforcement involved in reinforced concrete structures designed for long-term operation (more than 50...60 years). Thus, the obtained diagram can be recommended to designers of reinforced concrete structures for hydraulic purposes, as it greatly facilitates the reasonable choice of reinforcement in the development of reinforced concrete structures for responsible and long-term use.

Table 7 below shows the data of hot-rolled steel grade $09 Г 2 Ф Б$, from which were made 
on a rolling mill reinforcing bars for experimental tests.

The chemical composition of carbon steel grade 20 is as follows: $\mathrm{C} 0.17 \ldots 0.24$; Mn 0.25...0.65; Si 0.17...0.37; P 0.036; S 0.04 .

The normative and actual composition and mechanical properties of $16 \Gamma 2 \mathrm{~A} \Phi$ steel are given in Table 8 and 9.

Table 10 shows the experimental tests of experimental steels to determine the criteria for crack resistance, taken from modern fracture mechanics - the parameters of brittle fracture resistance $\mathrm{K}_{1 \mathrm{C}}$ and $\delta_{\mathrm{C}}$ and the parameter of microcracking $\mathrm{R}_{\mathrm{MC}}$, which are sensitive to metal structure, which changes during longterm operation. The studies were performed on samples according to the methods described in works $[1,3]$ the results of factory laboratory tests are shown in Table 10.

Table 6. Mechanical characteristics and criteria of crack resistance of steel 09Г2ФБ

\begin{tabular}{|c|c|c|c|c|c|c|c|c|c|}
\hline \multirow{2}{*}{$\begin{array}{l}\text { Chemical steel } \\
\text { composition, \% }\end{array}$} & $\sigma_{\mathrm{B}}$ & $\sigma_{0.2}$ & \multirow{2}{*}{$\begin{array}{r}\delta_{\mathrm{C}} \\
\%\end{array}$} & \multicolumn{2}{|c|}{$\mathrm{KCV}, \mathrm{MJ} / \mathrm{m} 2$} & \multicolumn{2}{|c|}{$\mathrm{K}_{1 \mathrm{C}}, \mathrm{MPa}+\mathrm{m}^{1 / 2}$} & \multicolumn{2}{|c|}{$\delta_{\mathrm{C}}, \mathrm{mm}$} \\
\hline & & & & $-40^{\circ} \mathrm{C}$ & $-20^{\circ} \mathrm{C}$ & $+20^{\circ} \mathrm{C}$ & $-20^{\circ} \mathrm{C}$ & $+20^{\circ} \mathrm{C}$ & $-20^{\circ} \mathrm{C}$ \\
\hline $\begin{array}{c}\text { C } 0.13 ; \\
\text { Mn 1.7..1.9; } \\
\text { Si } 0.35 \ldots 0.40 ; \\
\text { V } 0.09 \ldots 0.1 ; \\
\text { Nb } 0.05 \ldots 0.07 ; \\
\text { S, P } 0.01 \ldots 0.02\end{array}$ & 560 & 435 & $\begin{array}{c}19 \ldots \\
22\end{array}$ & $\begin{array}{c}0.6 \ldots \\
0.7\end{array}$ & 0.8 & $\begin{array}{c}98.5 \ldots \\
102.3\end{array}$ & $\begin{array}{l}90 \ldots \\
95.4\end{array}$ & $\begin{array}{c}0.7 \ldots \\
0.75\end{array}$ & $\begin{array}{c}0.47 \ldots \\
0.52\end{array}$ \\
\hline
\end{tabular}

Table 7. Impact strength of steel 09Г2ФБ

\begin{tabular}{|c|c|c|c|c|}
\hline \multirow{3}{*}{} & \multicolumn{4}{|c|}{ Impact strength and fracture fiber } \\
\cline { 2 - 5 } & \multicolumn{2}{|c|}{ according to Menage } & $\mathrm{KCV}, \mathrm{MJ} / \mathrm{m}^{2}$ & $\mathrm{~V}, \%$ \\
\cline { 2 - 5 } & $\mathrm{KCV}, \mathrm{MJ} / \mathrm{m}^{2}$ & $\mathrm{~B}, \%$ & $0.52 \ldots 1.1$ & $35 \ldots 75$ \\
\hline & $0.84 \ldots 1.35$ & $50 \ldots 70$ & $0.10 \ldots 0.35$ & $10 \ldots 15$ \\
\hline & $0.26 \ldots 0.94$ & 0 & $0.12 \ldots 0.50$ & 0 \\
\hline
\end{tabular}

Table 8. Chemical composition of $16 \Gamma 2 \mathrm{~A} \Phi$

\begin{tabular}{|c|c|c|c|c|c|c|c|}
\hline $\mathrm{C}$ & $\mathrm{Mn}$ & $\mathrm{Si}$ & $\mathrm{V}$ & $\mathrm{N}$ & $\mathrm{S}$ & $\mathrm{P}$ & $\mathrm{Al}$ \\
\hline \multicolumn{7}{|c|}{ Actual (as delivered) } \\
\hline $0.13 \ldots$ & $1.6 \ldots$ & $0.32 \ldots$ & $0.061 \ldots$ & $0.011 \ldots$ & $0.012 \ldots$ & $0.01 \ldots$ & $0.004 \ldots$ \\
0.15 & 1.66 & 0.40 & 0.095 & 0.013 & $0.022-$ & 0.014 & 0.026 \\
\hline \multicolumn{7}{|c|}{ Requirements TU $14-3-1138-82$} \\
\hline $0.11 \ldots$ & $1.1 \ldots$ & $0.20 \ldots$ & $0.06 \ldots$ & $0.010 \ldots$ & 0.020 & 0.025 & $0.015 \ldots$ \\
0.17 & 1.70 & 0.40 & 0.10 & 0.020 & & & 0.050 \\
\hline
\end{tabular}

Table 9. Mechanical properties of steel 16Г2АФ

\begin{tabular}{|c|c|c|c|c|c|}
\hline$\sigma_{\mathrm{v}}, \mathrm{MPa}$ & $\sigma_{0.2}, \mathrm{MPa}$ & $\delta, \%$ & $\mathrm{KCV}_{\mathrm{O}}, \mathrm{MJ} / \mathrm{m}^{2}$ & $\mathrm{KCU},{ }_{40} \mathrm{MJ} / \mathrm{m}^{2}$ & $\mathrm{~V}$ under $0^{\circ} \mathrm{C}, \%$ \\
\hline \multicolumn{7}{|c|}{ Actual } \\
\hline $566 \ldots 601$ & $400 \ldots 460$ & $21 \ldots 27$ & $0.48 \ldots 0.73$ & $0.49 \ldots 0.65$ & $25 \ldots 90$ \\
\hline \multicolumn{7}{|c|}{$\mathrm{TU}$ requirements } \\
\hline $540 \ldots 640$ & $370 \ldots 470$ & $\geq 19$ & $\geq 0.4$ & $\geq 0.5$ & $\geq 60$ \\
\hline
\end{tabular}


Table 10. Parameters of crack resistance of experimental steels

\begin{tabular}{|c|c|c|c|c|c|c|c|c|c|}
\hline \multirow{3}{*}{ Steel brand } & \multicolumn{3}{|c|}{$\mathrm{K}_{1 \mathrm{C}}, \mathrm{MPa}+\mathrm{m}^{1 / 2}$} & \multicolumn{3}{|c|}{$\delta_{\mathrm{C}}, \mathrm{mm}$} & \multicolumn{3}{|c|}{$\mathrm{R}_{\mathrm{MS}}, \mathrm{MPa}$} \\
\hline & \multicolumn{9}{|c|}{ Test temperature, ${ }^{\circ} \mathrm{C}$} \\
\hline & +20 & -20 & -40 & +20 & -20 & -40 & +20 & -20 & -40 \\
\hline $16 Г 2 А \Phi$ & 99.8 & 81.5 & 72.1 & 0.72 & 0.49 & 0.39 & 897 & 784 & 595 \\
\hline $20 \Phi$ & 88.7 & 78.3 & 66.8 & 0.71 & 0.68 & 0.60 & 798 & 680 & 501 \\
\hline 15ХСНДА & 105.6 & 98.0 & 83.5 & 0.82 & 0.72 & 0.67 & 925 & 823 & 675 \\
\hline 10ХСНДА & 88.9 & 80.2 & 70.1 & 0.68 & 0.60 & 0.52 & 780 & 692 & 578 \\
\hline 09Г2ФБ & 111.4 & 98.5 & 82.5 & 0.88 & 0.79 & 0.62 & 956 & 856 & 670 \\
\hline $06 Г 2 Б$ & 90.2 & 85.9 & 75.7 & 0.82 & 0.73 & 0.69 & 950 & 870 & 658 \\
\hline 08ХМЧА & 121 & 88.7 & 79.2 & 0.92 & 0.78 & 0.73 & 1123 & 934 & 789 \\
\hline
\end{tabular}

It should be noted that the use of vanadium modifier in steels (example steel 09Г2ФБ). As a rule, the content of vanadium in steels is limited to $0.1 \%$, with a content of vanadium of $0.1 \ldots 0.15 \%$ there is no further crushing of the grain, toughness at low temperatures decreases $[6,8 \ldots 10]$, i.e. in the case of production of low-alloy steel vanadium should be introduced in the amount of up to $0.1 \%$.

The use of niobium as a steel modifier has shown that it weakly deoxidizes steel, but at the same time is a strong carbide-forming element. In the presence of nitrogen in steel can form carbonitrides. Experiments have shown that the most favorable effect of niobium in small quantities (approximately $0.02 \ldots 0.03 \%$ ) and especially in combination with aluminum (about $0.02 \%$ ). In this case, the strength and yield strength increase (by $40 \mathrm{MPa}$ ), the tendency of steel to age decreases, and so on.

In general, microalloying of low-alloy normalized steel with carbide- and nitrideforming elements slightly increases their service properties. Application of these elements in steels of the controlled rolling allows to receive higher properties on all indicators.

Microalloying of low-alloy steel (for example, 06X1) with a rare earth element - cerium in the amount of $0.02 \ldots 0.03 \%$ leads to globulation of non-metallic inclusions, the amount of oxides decreases. The positive effect of cerium on viscosity is due to its effect on the shape and amount of non-metallic inclusions, as well as to some grain crushing. The mechanism of influence of rare earth metals (REM) on the properties of steel is insufficiently studied. However, the positive effect of REM on the shape of non-metallic inclusions is not in doubt. Treatment of reinforcing steels with cerium in the amount of $0.02 \ldots 0.03 \%$ promotes high-quality rolled products with high corrosion-mechanical properties and which can be used in the construction of reinforced concrete structures.

We analyzed the picture of the deformed state of the steel fittings of the conventional grade 08XMЧA (micromodified with cerium) at the crack tip. Fracture scans at the ends of the fracture were examined by fracture scanning (YSM-35CF microscope model (Jeol, Japan)). Softening of the metal (Fig. 3) to $60 . .70 \%$ of the original, which can be considered as the accumulation of damage caused by microplastic deformation. However, the front of this quasi-stationary zone, which moves in front of the crack apex, is small and forms a layer $\approx 80 \mu \mathrm{m}$ thick along the crack depth and $60 \ldots 70 \mu \mathrm{m}$ along its walls, i.e. destruction in this case is usually quasi-brittle.

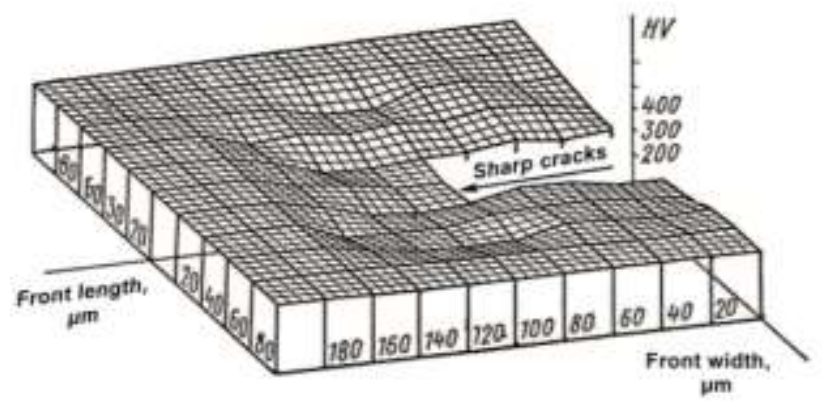

Fig. 3. Picture of metal softening before the crack front in reinforcing steel 08XMЧA with corrosion cracking in the model environment NACE 
It is known that simultaneously with plastic deformation, relaxation processes take place intensively. This zone is characterized by plastic deformation by internal grain slip, and therefore dislocations are concentrated mainly in the sliding strips. Next, the parent metal with the original dislocation structure is observed. The maximum density of dislocations is observed in the zone with significant residual plastic deformation, which reaches an average of $2 \%$ (total relative deformation), $10 \%$ or more in microvolumes. associated with local shifts (Fig. 4).

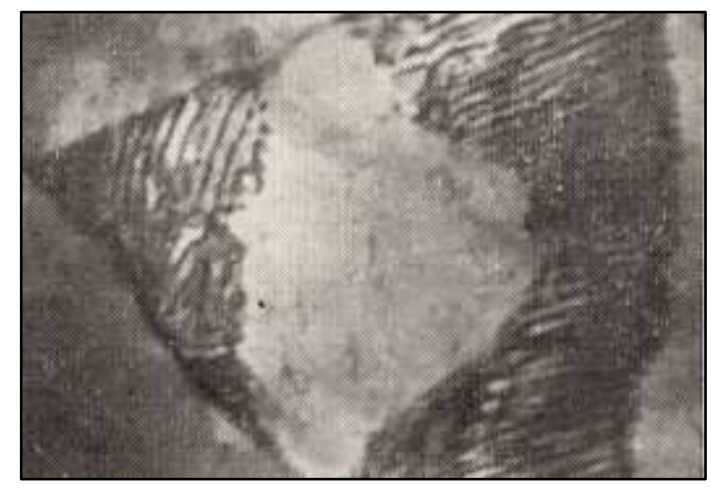

Fig. 4. Dislocation structure of deformed reinforcing steel 08XMЧA (x25000)

Next, consider the role of sulfur in the mechanical properties of the metal. It is widely known that sulfur adversely affects the properties of steel. Sulfur in the metal is usually present in the form of non-metallic inclusions, mainly manganese sulfides. It is established $[2,3]$ to increase the sulfur content by 0.015 in the range $0.02 \ldots 0.005$ shifts the critical brittleness temperature to the region of positive temperatures by $15^{\circ} \mathrm{C}$. The amount of sulfur in normalized steels is reduced by metallurgists to $0.02 \%$, and in controlled rolling steels - to $0.004 \%$ and below, which increases the toughness (according to Sharpe) almost 2 times. Low sulfur content $(0.005 \ldots 0.01 \%)$ significantly increases the positive effect of cerium steel treatment, which significantly increases the crack resistance of steel.

Steels with a tempering sorbitol structure have the highest survivability. This is due to the low growth rate of the fatigue crack, due to the high ductility of the metal (see Fig. 2) and the presence of a developed substructure of the ferritic phase of sorbitol. The dislocation walls that separate the ferrite grains serve as barriers to the fatigue crack, which causes it to change direction in a zigzag pattern and spend more energy and time growing to a critical size. In addition, the steel after heat treatment for tempering sorbitol becomes insensitive to the appearance of stress concentrators and accidental shock load.

Steel heat-treated for tempering or tempering martensite has a higher $\sigma_{-1}$, but its significant resistance to the formation of fatigue cracks is neutralized by increased sensitivity to surface quality. In addition, high-strength steels are characterized by low resistance to cracking.

Thus, operating conditions require a special combination of high resistance to fatigue crack formation and high resistance to its propagation, which is almost impossible to provide in reinforcing steel using alloying and heat treatment. This problem is solved by the use of surface hardening technologies (surface plastic deformation, chemical-thermal treatment (CTT), surface hardening) for low- or medium-carbon steels treated with the structure of tempering sorbets. The result is steels with a strong surface and a viscous plastic core [11, 12].

\section{CONCLUSIONS}

1. It is shown that structural inhomogeneity promotes the passage of non-uniform deformation in the volume of the metal. In turn, the higher the inhomogeneity of the deformation, the less deformation the plasticity of the metal will be exhausted, the earlier the fracture will occur, as observed in the experiments. The obtained experimental results must be taken into account in the construction of galleries of underground sewer systems by introducing into the regulatory and technological documentation of these steels in relation to the design and construction of responsible reinforced concrete structures.

2 . The physical characteristics of $\alpha \mathrm{Fe}$-phase in steels 10ХСНДА and 15ХСНДА, in particular, the number of dislocations does not exceed $(155-220) \cdot 10^{9} \mathrm{~cm}^{-2}$, and the amplitude of 
curvature of the crystal lattice does not exceed $560 \ldots 650 \mathrm{~cm}^{-1}$, which is characteristic of the ferritic-pearlitic phase. And the stresses are mostly elastic, not relaxed. In addition, in the field of crystals and along the boundaries of the $\alpha$-phase carbide phases are not established, which will increase the crack resistance of reinforcing steel during long-term operation at alternating loads.

3. It is established that steels $16 \Gamma 2 \mathrm{~A} \Phi$, 09Г2ФБ and $15 Х \mathrm{XСДА} \mathrm{have} \mathrm{a} \mathrm{reserve} \mathrm{of}$ plasticity and ability to resist destruction at plastic deformations. In addition, these steels are characterized by high resistance to brittle fracture, and therefore they can be recommended for the manufacture of reinforcement of reinforced concrete structures designed for the perception of high alternating loads during operation in aggressive environments.

4. It is shown that the highest values of modern criteria of crack resistance are steels 16Г2АФ, 09Г2ФБ and 15ХСНДА, which are economically modified with vanadium, niobium, chromium, nickel, copper and have a very low sulfur content. This class of steels includes experimental steel of the conventional grade 08XMЧA, which is economically modified with cerium $(0.025 \ldots 0.03 \%)$.

\section{REFERENCES}

1. Makhutov N.A., 1981. Deformation criteria of destruction. Moscow: Mashinostroenie, 272 (in Russian).

2. Archakov Yu.I., 1980. Hydrogen corrosion of steel. Moscow: Metallurgy ,192 (in Russian).

3. Atomic mechanism of destruction, 1983, trans., ed. MA Stremel. Moscow: Mir, 660 (in Russian).

4. Kalachev B.A., (1985). Hydrogen brittleness of metals. Moscow: Metallurgy,216. (in Russian)

5. Meshkov Yu.Ya.,1985. Physical foundations of the strength of steel structures. Kiev: Naukova Dumka, 266 (in Russian).

6. Petrov L.N. Sopronyuk N., 1988. Corrosionmechanical destruction of metals and alloys. Kiev: Naukova Dumka ,488 (in Russian).

7. Moskvin V.M., 1980. Corrosion of concrete and reinforced concrete methods of their protection. Moscow: Stroyizdat. 538.
8. Makarenko V.D., Mangura A.M., Sizonenko A.V., Litvyak O.L., 2019. Mechanisms of corrosion-carbon corrosion of structural tubular steels for oil and gas application Modernization and engineering development of resourcesaving technologies in mining and processing of minerals. Collective monograph. Petroshan, Romania UNIVERSITAS Publishing, 424 (57 70).

9. Makarenko V., Vynnykov Y., Liashenko A., Petrash O., 2019. Hydrate Formations Modeling for the Oil and Gas Facilities Reconstruction, Proceedings of the 2nd International Conference on Building Innovations. ICBI. Lecture Hydrate Formations Modeling for the Oil and Gas Facilities Reconstruction Notes in Civil Engineering, Vol.73. Springer, Cham. 651-658.

10.Boyko A.V., Makarenko V.D., Maximov S.Yu., 2021. On some mechanical characteristics of structural steels of cooling systems of long operation. Problems of durability, No.2 (470), 77-81.

11.Makarenko, V.D., \& Morgun, I.D., 1991. Special features of the effect of barium on the mechanical properties of metal deposited in welding with calcium fluoride electrodes. Welding International, 5(9), 726-728.

12.Pokhodnya, I.K., Ponomarev, V.E., Milichenko, S.S., Skorina, N.V., Makarenko, V. D., Marchenko, A.E., \& Gorpenyuk, V.N., (1987). Effects of type of binder and its composition on the welding and properties of electrodes with basic coatings. Welding International, 1(2), 116-118.

13.Petrenko E., Gharakhanlou M., (2015). Analysis of slope at increase of the static load. Underwater Technologies, Iss.02, 40.

14.Pushkarova K., Sukhanevych M., Bondar K., 2015. The principles of composite construction penetrability waterproofing mortars with increased service life. Underwater Technologies Iss.02, 46.

15.Mishchuk D., 2015. Research of the manipulator dynamics installed on an elastic basis. Underwater Technologies, Iss.02, 54.

16.Sukach M.K., 2017. Elastic suspension of vehicles. Mining, construction, road and melioration machines, No.90, 73-78 https://doi.org/10.26884/mksu.a17293 Ukrainian).

17.Horbatenko Y., 2020. The production of the splash phenomenon, as a way of dissipating the energy of a gravitational wave. Underwater Technologies, Iss. 10, 58 
18.Sukach M.K., 2021. The Staple-ShapePlate Springs Engineering Calculation Method. Science and Technique, 20 (3), 268-274, https://doi.org/10.21122/2227-1031-2021-20-3 (in Russian).

19.Sukach M.K., Lysak S., 2017. Kinematics parameters of twosectional trencher's. Underwater Technologies, Iss.05, 16-22. https://doi.org/10.26884/uwt1705.1301.

\section{Исследование механических свойств и па- раметров трещиностойкости стальных укреплений железобетонных конструкций долгосрочного специального срока}

Петр Куликов, Юлия Макаренко, Виктор Хоружсий, Валерий Макаренко

Аннотация. Известно, что процесс усталости начинается с пластической деформации поверхностных слоев металлической арматуры. Причем смещение дислокаций в условиях знакопеременных нагрузок наблюдается при нагрузках ниже предела упругости металла. Скорость локальной пластической деформации при циклической деформации на несколько порядков превышает скорость деформации при статическом нагружении. Дислокационное скольжение начинается в зернах с благоприятной ориентацией вблизи концентраторов напряжений. С увеличением количества циклов в поверхностных слоях увеличивается плотность дислокаций и количество вакансий. При достижении базового числа циклов $\mathrm{N}_{\mathrm{R}}$ образуется поверхностно-армированный слой металла с большим количеством зародышевых трещин, размер которых не достигает критического значения. Увеличение количества циклов не может привести к дальнейшему развитию разрушения в таком слое. Только когда напряжения превы- шают предел выносливости трещины, достигают критической длины, после чего начинается процесс их разряда в магистральную трещину с распространением последней. Результаты экспериментальных исследований указывают на сильное влияние диффузионного водорода на статические и циклические параметры трещиностойкости. Было обнаружено, что с увеличением затопления, особенно когда содержание водорода превышает $5 \mathrm{~cm}^{3} / 100$ г, как статическая прочность, так и длительная прочность (усталость) резко снижаются. Причем для этих участков раствор водорода в арматурной стали характеризуется вязким характером разрушения, тогда как для сильно обводненной арматуры (от 5 до $12 \mathrm{~cm}^{3} / 100$ г характерно хрупкое разрушение по механизму микроделения в закаленной (мартенситной или трооститовой конструкции). позволили определить оптимальное содержание водорода в арматурной стали $\left(3 \ldots 5 \mathrm{~cm}^{3} / 100\right.$ г), превышение которого снизит трещино-стойкость арматуры при длительной эксплуатации, особенно в агрессивных средах. Результаты исследований подтверждают приведенные выше данные, структура бейнита резко снижает трещиностойкость арматурной стали, что делает невозможным использование при изготовлении арматуры железобетонных конструкций, рассчитанных на длительную эксплуатацию (более $50 . .60$ лет). Полученную схему можно рекомендовать проектировщикам железобетонных конструкций гидротехнического назначения, так как она значительно облегчает обоснованный выбор конструкции. армирование при разработке железобетонных конструкций ответственного и длительного использования.

Ключевые слова: трещиностойкость, затопление, усталость, цикличность, арматура. 